\title{
Development of a new air-stable structure-simplified nafuredin- $\gamma$ analog as a potent and selective nematode complex I inhibitor
}

\author{
Masaki Ohtawa ${ }^{1,4}$, Shiho Arima ${ }^{1,4}$, Risa Shimizu ${ }^{1}$, Naomi Hanatani ${ }^{1}$, Eri Shimizu ${ }^{1}$, Kazuro Shiomi ${ }^{2}$, \\ Kiyoshi Kita ${ }^{3}$, Satoshi Ōmura ${ }^{1,2}$ and Tohru Nagamitsu ${ }^{1}$
}

Nafuredin- $\gamma$, obtained from natural nafuredin, has demonstrated a potent and selective inhibitory activity against nematode complex I. However, nafuredin- $\gamma$ is unstable in air since its conjugated dienes are oxygen-labile. The instability in air was naturally solved by the synthesis of structure-simplified nafuredin- $\gamma$ analogs without conjugated dienes. However, these modified analogs showed lower complex I inhibitory activities. Therefore, new air-stable structure-simplified nafuredin- $\gamma$ analogs were designed and synthesized herein. Among all analogs synthesized, the one bearing a unique 1-azabicyclo[3.1.0]hexane scaffold showed the highest inhibitory activity $\left(\mathrm{IC}_{50}=170 \mathrm{~nm}\right)$ while presenting high selectivity against nematode complex I.

The Journal of Antibiotics (2017) 70, 647-654; doi:10.1038/ja.2017.16; published online 22 February 2017

\section{INTRODUCTION}

Nafuredin $(\mathbf{1})^{1-3}$ was isolated from the fermentation broth of the fungal strain Aspergillus niger FT-0554 while screening for selective complex I inhibitors and proved to be a potent and selective inhibitor against nematode complex I. In addition, 1 demonstrated anthelmintic activity against Haemonchus contortus during in vivo trials with sheeps. ${ }^{1} \mathrm{~A}$ total synthetic study of $\mathbf{1}$ subsequently identified a novel and structurally simpler $\gamma$-lactone compound, nafuredin- $\gamma(2)$, which was generated from 1 under mild basic conditions. ${ }^{4-6}$ Moreover, the nematode complex I inhibitory activity of $\mathbf{2}$ was identical to that of $\mathbf{1}$. Therefore, nafuredin (1) and nafuredin- $\gamma$ (2) holds promise as a selective antiparasitic agent. However, these compounds are disadvantageous in that they have poor air stability owing to the presence of oxygen-labile conjugated diene units (Figure 1). The total synthesis of $\mathbf{2}$ has been achieved by our group. ${ }^{7}$ Several nafuredin- $\gamma$ analogs were then synthesized using this total synthesis approach and their complex I inhibitory activities were examined. Consequently, the importance of the stereochemistries of C4 and C5 for the complex I inhibitory activity of these compounds was revealed. Next, we attempted the synthesis of structure-simplified nafuredin- $\gamma$ analogs lacking the oxygen-labile conjugated diene units to solve the instability of $\mathbf{1}$ and $\mathbf{2}$ in air. Thus, we found that a new nafuredin- $\gamma$ analog 3 obtained by a concise synthesis approach showed moderate complex I inhibitory activity while having high air stability (Figure 2). ${ }^{8}$

To improve the nematode complex I inhibitory activity of air-stable nafuredin- $\gamma$ analogs, additional structure-activity relationship studies were carried out over 3 . Thus, the length of the isoprene unit as a side chain was changed originating new targets 4-6. Additionally, the tetrahydrofuran (THF) unit was replaced by pyrrolidine or tetrahydrothiophene units to generate new targets 7 and $\mathbf{8}$ (Figure 2). Subsequent biological evaluation revealed some of the newly synthesized air-stable nafuredin- $\gamma$ analogs to be more potent nematode complex I inhibitors than 3 . Herein, we report new structure-activity relationship studies of air-stable structure-simplified nafuredin- $\gamma$ analogs as nematode complex I inhibitors.

\section{RESULTS AND DISCUSSION}

We first embarked on the synthesis of new analogs $\mathbf{4 - 6}$ by varying the length of the isoprene unit (Scheme 1) through our previously developed synthetic route. ${ }^{8}$ tert-Butyldimethylsilyl protection, deacetylation by methanolysis and sharpless asymmetric epoxidation of a known allyl acetate $\mathbf{9}^{9}$ gave chiral epoxyalcohol 10 , which was subjected to Appel reaction ${ }^{10}$ to afford iodide 11. Introduction of the side chain moiety was achieved by coupling the epoxyiodide $\mathbf{1 1}$ with the corresponding known sulfones 12-14. ${ }^{11,12}$ Subsequent Pdcatalyzed reductive desulfonylation ${ }^{13}$ afforded 15-17 (the synthesis of intermediate 17 was not optimized. Because our primary interest was in evaluating the nematode complex I inhibitory activity of the new analog 6.). Finally, deprotection of the tert-butyldimethylsilyl group and acid-catalyzed cyclization gave desired analogs 4-6.

The inhibitory activities against nematode complex I of 4-6 were evaluated (Table 1, also see experimental section) ${ }^{1,14}$ Analogs 4 and 5, possessing shorter side chains $(n=0$ or 1$)$ than nafuredin- $\gamma$ (2) and air-stable nafuredin- $\gamma$ analog 3 , exhibited very low complex I

\footnotetext{
${ }^{1}$ Graduate School of Pharmaceutical Sciences, Kitasato University, Tokyo, Japan; ${ }^{2}$ Graduate School of Infection Control Sciences, Kitasato University, Tokyo, Japan and ${ }^{3}$ School of Tropical Medicine and Global Health, Nagasaki University, Nagasaki, Japan

${ }^{4}$ These authors contributed equally to this work.

Correspondence: Professor T Nagamitsu, Graduate School of Pharmaceutical Sciences, Kitasato University, 5-9-1 Shirokane, Minato-ku, Tokyo 108-8641, Japan.

E-mail: nagamitsut@pharm.kitasato-u.ac.jp

Received 17 October 2016; revised 27 December 2016; accepted 16 January 2017; published online 22 February 2017
} 
inhibitory activities as compared with 3 . Analog 6 with a longer side chain $(n=3)$ showed a moderate inhibitory activity and still lower than that of $3(n=2)$. Therefore, analog 3 proved to have the optimum side chain length in terms of complex I inhibitory activity.
Next, we investigated the synthesis of new analogs $\mathbf{7}$ and $\mathbf{8}$ bearing pyrrolidine or tetrahydrothiophene units instead of THF (Scheme 2) while maintaining the same side chain of 3 . Coupling of iodide 9 with sulfone $18^{15}$ followed by $\operatorname{Pd}(0)$-catalyzed desulfonation gave 19 , which<smiles>CCC(C)/C=C/C=C(\C)C[C@H](C)/C=C/C=C/[C@H]1OC(=O)[C@H](O)[C@H]2O[C@]12C</smiles>

Nafuredin (1) $\left(\mathrm{IC}_{50}=12 \mathrm{nM}\right)$<smiles>CC[C@H](C)/C=C/C=C(\C)C[C@H](C)/C=C/C=C/[C@@H](O)[C@]1(C)C=C(O)C(=O)O1</smiles>

Nafuredin- $\gamma(2)$

$\left(\mathrm{IC}_{50}=6 \mathrm{nM}\right)$

Figure 1 Structures and complex I inhibitory activities of nafuredin (1) and nafuredin- $\gamma(\mathbf{2})$.

Previous work $^{8}$<smiles>CC(C)=CCC/C(C)=C/CC/C(C)=C/CCC(O)[C@]1(C)CCCO1</smiles>

3

$\left(\mathrm{IC}_{50}=500 \mathrm{nM}\right)$ stable in air
Simplification of lactone

and isoprene units

- Lower complex I inhiibitory activity than 2

but still maintains high activity

- Obtained by a concise synthesis

- Air-stable
This work

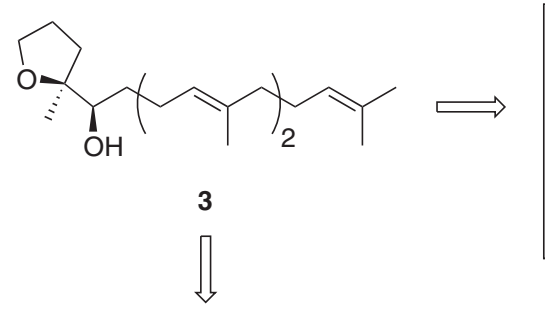

2) Replacement by pyrrolidine or tetrahydrothiophene

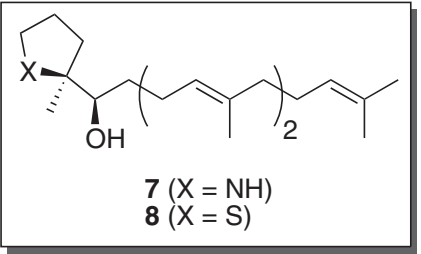

Figure 2 Air-stable structure-simplified nafuredin- $\gamma$ analogs synthesized and designed by our group.

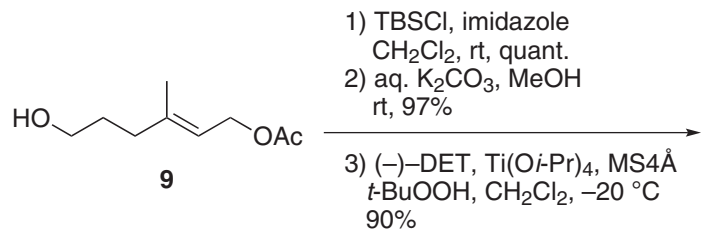

TBSCl, imidazole

要, quant.

aq. $\mathrm{K}_{2} \mathrm{CO}_{3}, \mathrm{MeOH}$

(-)-DET, Ti(Oi-Pr) $4, \mathrm{MS} 4$ $90 \%$

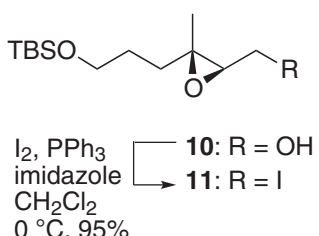

$0{ }^{\circ} \mathrm{C}, 95 \%$

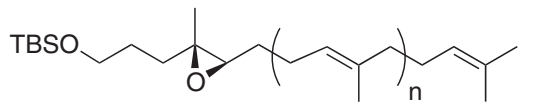

15: $\mathrm{n}=0$

16: $\mathrm{n}=1$

17: $n=3$
1) TBAF, THF, rt

2) PPTS, $\mathrm{CH}_{2} \mathrm{Cl}_{2}$, rt

4: $97 \%$ (2 steps), 5: 94\% (2 steps),

6: $71 \%$ (2 steps)
1) Change in the length of isoprene unit

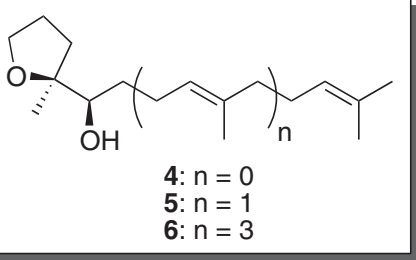

5: $n=1$

Scheme 1 Synthesis of air-stable structure-simplified nafuredin- $\gamma$ analogs 4-6.

1) $\mathrm{PhO}_{2} \mathrm{~S}$

$12(n=0)$ or $13(n=1)$ or $14(n=3)$ $n$-BuLi, HMPA, THF, $-78^{\circ} \mathrm{C}$

2) $\mathrm{Pd}(\mathrm{OAc})_{2}, \mathrm{dppp}$

$\mathrm{NaBH}_{4} \mathrm{DMSO}$, it

15: $76 \%$ (2 steps), 16: 73\% (2 steps)

17: $27 \%$ (2 steps)

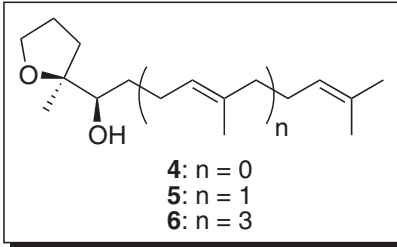


Table 1 Inhibitory activities of 3-6 against nematode complex I

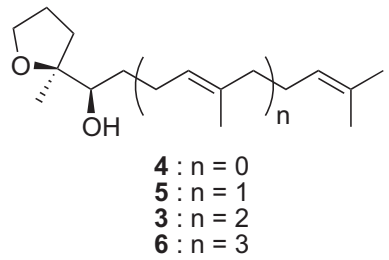

\begin{tabular}{ll}
\hline Compond & $I_{50}(\mathrm{~nm})$ \\
\hline $\mathbf{4}$ & $>4.0 \times 10^{4}$ \\
$\mathbf{5}$ & $2.3 \times 10^{3}$ \\
$\mathbf{3}$ & $5.0 \times 10^{2}$ \\
$\mathbf{6}$ & $8.0 \times 10^{2}$ \\
\hline
\end{tabular}

was subjected to deprotection of tert-butyldimethylsilyl ether and tosylation to afford tosylate $20 . \mathrm{S}_{\mathrm{N}} 2$ reaction of 20 with potassium phthalimide and potassium thioacetate yielded phthalimide 21 and thioacetate 22 , respectively.

First, phthalimide 21 was exposed to a solution of hydrazine (4 equiv.) in $\mathrm{THF}$ at $50^{\circ} \mathrm{C}$ (Scheme 2, condition A) for synthesizing pyrrolidine analog 7. Surprisingly, unexpected aziridine analog 23 bearing a unique 1-azabicyclo[3.1.0] hexane scaffold was obtained as a major product (61\%) accompanied with desired pyrrolidine analog $7(10 \%)$ as a minor product. The structure of aziridine analog 23 was determined by NOESY and HMBC spectroscopy. We speculated that aziridine analog 23 can be stereoselectively derived from desired pyrrolidine analog 7 via dehydration under high temperature conditions. This reaction was subsequently carried out at room temperature and the yield of 7 was slightly improved (27\%) although 23 was also obtained in similar yield (23\%) along with

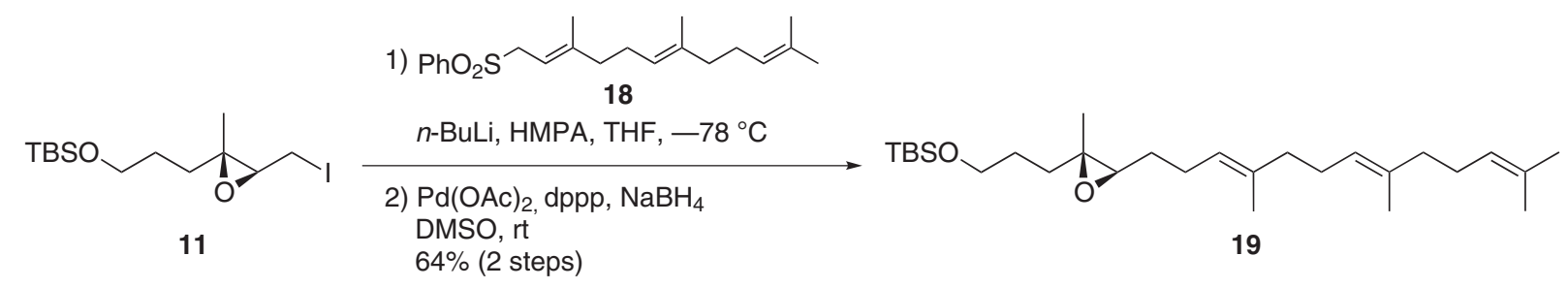

1) TBAF, THF, rt

2) $\mathrm{TsCl}_{2} \mathrm{Et}_{3} \mathrm{~N}, \mathrm{Me}_{3} \mathrm{~N} \cdot \mathrm{HCl}$

$\mathrm{CH}_{2} \mathrm{Cl}_{2}, 0^{\circ} \mathrm{C}$

93\% (2 steps)

次

20

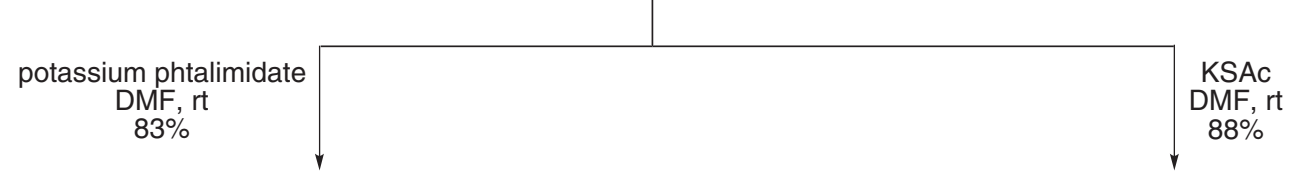<smiles>CC(C)=CCC/C(C)=C/CC/C(C)=C/CCC1OC1(C)CCCN1C(=O)c2ccccc2C1=O</smiles>

21

Condition $\mathbf{A}$

$\mathrm{NH}_{2} \mathrm{NH}_{2} \cdot \mathrm{H}_{2} \mathrm{O}$ (4 eq.)

THF, $50{ }^{\circ} \mathrm{C}$

7: $10 \%, 23: 61 \%$<smiles>CC(C)=CCC/C(C)=C/CC/C(C)=C/CCC(O)[C@]1(C)CCCN1</smiles>

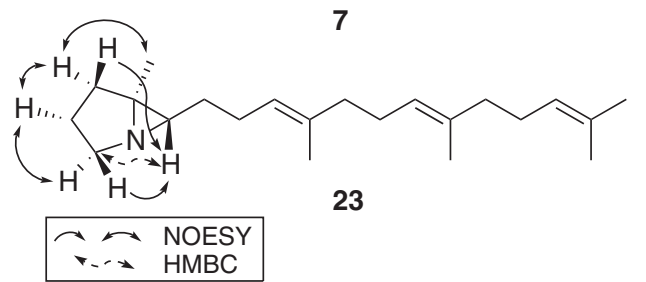<smiles>CC(C)=CCCC(C)=CCCC(C)=CCCC1OC1(C)CCC[AsH3]</smiles>

22

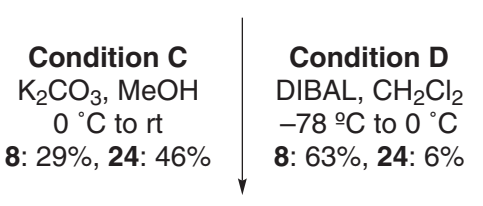<smiles>CC(C)=CCC/C(C)=C/CC/C(C)=C/CCC(O)[C@@H]1CCCS1</smiles>

8<smiles>[Z4]C(C)=CCCC1SCCC[C@]1(C)O</smiles>

Scheme 2 Synthesis of air-stable structure-simplified nafuredin- $\gamma$ analogs 7, 8, 23 and 24. 
<smiles>CC(C)=CCC/C(C)=C/CC/C(C)=C/CCC(O)[C@]1(C)CCCO1</smiles>

3<smiles>[3H]/C(=C\CC[C@@H](O)[C@]1(C)CCCN1)CC/C=C(\C)CCC=C(C)C</smiles><smiles>CC(C)=CCC/C(C)=C/CC/C(C)=C/CCC(O)[C@]1(C)CCCS1</smiles><smiles>CC(C)=CCC/C(C)=C/CC/C(C)=C/CCC1CN2CCC[C@]12C</smiles>

23

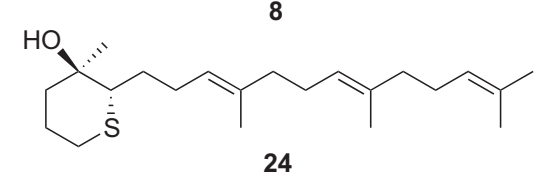

\begin{tabular}{lr} 
Compond & IC 50 (nM) \\
\hline 3 & $5.0 \times 10^{2}$ \\
7 & $3.0 \times 10^{2}$ \\
23 & $1.7 \times 10^{2}$ \\
8 & $1.6 \times 10^{3}$ \\
24 & $1.2 \times 10^{3}$ \\
\hline
\end{tabular}

the recovered starting material 21 (28\%) (data not shown). To completely consume the starting material, the reaction was carried out with higher concentrations of hydrazine (20 equiv.) at room temperature (Scheme 2, condition B) to afford the desired pyrrolidine analog 7 in 58\% yield along with traces of the aziridine analog 23 .

With the thioacetate $\mathbf{2 2}$ in hand, the synthesis of tetrahydrothiophene analog 8 was also attempted. Methanolysis of 22 followed by epoxide-opening cyclization afforded a separable mixture of desired tetrahydrothiophene 8 (29\%) and tetrahydro-2H-thiopyran 24 (46\%) analogs (Scheme 2, condition C). In contrast to these results, diisobutylaluminum hydride reduction of 22 gave desired tetrahydrothiophene analog $8(63 \%)$ as a major product accompanied with minor amounts of tetrahydro- $2 H$-thiopyran analog $24(6 \%)$ (Scheme 2, condition D). Tetrahydro- $2 H$-thiopyran analog 24 is unfavorable according to the Baldwin rule. ${ }^{16}$ However, the steric hindrance under condition $\mathrm{C}$ might prevail to give 24 as a major product. On the other hand, the regioselectivity under condition D would contribute to a greater stabilization of the partial positive charge at the more hindered end of the epoxide, resulting by coordination to the oxygen atom of the epoxide by aluminum species.

Table 2 shows the inhibitory activities against nematode complex I of novel analogs 7, 8, 23 and 24 (also see experimental section). The complex I inhibitory activity of pyrrolidine analog 7 slightly increased as compared with THF analog 3. Interestingly, aziridine analog 23 exhibited the most potent complex I inhibitory activity $\left(\mathrm{IC}_{50}=170 \mathrm{~nm}\right)$ among all analogs synthesized. On the other hand, the complex I inhibitory activities of sulfur-containing analogs $\mathbf{8}$ and 24 greatly decreased as compared with to 3 . Aziridine analog 23 exhibited no inhibition activity against a bovine heart $\mathrm{NADH}$ oxidase including complexes I and III $(>20 \mu \mathrm{M}) .{ }^{14}$ This result indicated that aziridine analog 23 is a potent and selective inhibitor against nematode complex I.
In conclusion, novel air-stable structure-simplified nafuredin- $\gamma$ analogs, prepared by varying the length of side chain and by replacing the THF unit by pyrrolidine and tetrahydrothiophene, were designed and synthesized. In the course of the synthetic studies, we found out the new aziridine analog 23 , which is naturally stable in air and proved to be the most potent and selective inhibitor against nematode complex I among all analogs synthesized by our group. In vivo tests of aziridine analog 23 and further structure-activity relationship studies of the air-stable structure-simplified nafuredin- $\gamma$ analogs are currently underway in our laboratory.

\section{EXPERIMENTAL PROCEDURE}

\section{General}

All reactions were carried out in flame-dried glassware under a nitrogen atmosphere employing standard techniques for handling air-sensitive materials. Commercial reagents were used without further purification unless otherwise indicated. Organic solvents were distilled and dried over 3 or $4 \AA$ molecular sieves. Cold baths were prepared as follows: $0{ }^{\circ} \mathrm{C}$, wet ice/water; $-78^{\circ} \mathrm{C}$, dry ice/acetone. Purifications by flash column chromatography were performed

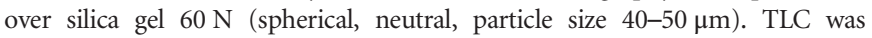
performed on $0.25 \mathrm{~mm}$ Merck silica gel $60 \mathrm{~F} 254$ plates and the effluents were visualized by UV $(254 \mathrm{~nm})$ as well as by phosphomolybdic acid and $p$-anisaldehyde TLC stains. Yields refer to chromatographically and spectroscopically pure compounds, unless otherwise noted. ${ }^{1} \mathrm{H}$ - and ${ }^{13} \mathrm{C}-\mathrm{NMR}$ spectra were recorded using an internal deuterium lock on 400-MR, VNMRS-400 and UNITY-400 spectrometers (Agilent Technologies, Waldbornn, Germany). All NMR signals were reported in ppm relative to the internal reference standard provided by chloroform (that is, 7.26 or $77.0 \mathrm{ppm}$ for the ${ }^{1} \mathrm{H}$ and ${ }^{13} \mathrm{C}$ spectra, respectively). Multiplicity data were presented as follows: $\mathrm{s}=$ singlet, $\mathrm{d}=$ doublet, $\mathrm{t}=$ triplet, $\mathrm{q}=$ quartet, $\mathrm{m}=$ multiplet, $\mathrm{br}=$ broad, $\mathrm{dd}=$ double doublet and $\mathrm{dt}=$ double triplet. Coupling constants $(J)$ were reported in Hz. IR spectra were recorded on a FT/IR460-plus IR spectrometer (JASCO, Tokyo, Japan). Absorption data were given in wavenumbers $\left(\mathrm{cm}^{-1}\right)$. Optical rotations were recorded on a JASCO DIP-1000 polarimeter (JASCO, Tokyo, Japan) and reported as follows: $[\alpha]^{\mathrm{T}} \mathrm{D}$, concentration (g per $100 \mathrm{ml}$ ), and solvent. High resolution mass spectra were obtained on JEOL JMS-700 
Mstation, JEOL JMS-AX505HA and JEOL JMS-T100LP systems (JEOL, Tokyo, Japan) equipped with FAB, EI and ESI high-resolution mass spectrometers.

\section{Enzyme assays}

The nematode complex I (NADH-fumarate reductase) activity was measured in assay mixtures containing $50 \mathrm{~mm}$ potassium phosphate $(\mathrm{pH} 7.2), 10 \mathrm{~mm}$ $\beta$-D-glucose, 20 units of glucose oxidase, 26 units of catalase and $200 \mu \mathrm{M}$ NADH. ${ }^{1}$ The reaction is started by the addition of sodium fumarate $(5 \mathrm{~mm})$. The absorbance change at $340 \mathrm{~nm}$ (millimolar extinction coefficient of 6.2 for $\mathrm{NADH}$ ) was followed. All inhibitory activities against nematode complex I $\left(\mathrm{IC}_{50}\right.$ values) in Tables 1 and 2 were the average of three independent experiments.

((2R,3R)-3-(3-((tert-Butyldimethylsilyl)oxy)propyl)-3-methyloxiran2-yl)methanol (10)

To a solution of $9(1.09 \mathrm{~g}, 6.30 \mathrm{mmol})$ in $\mathrm{CH}_{2} \mathrm{Cl}_{2}(63 \mathrm{ml})$ at $0{ }^{\circ} \mathrm{C}$ were added imidazole $(515 \mathrm{mg}, 7.56 \mathrm{mmol})$, tert-butyldimethylsilyl chloride $(1.14 \mathrm{~g}, 7.56 \mathrm{mmol})$ and dimethylaminopyridine $(38.5 \mathrm{mg}, 0.320 \mathrm{mmol})$. The mixture was stirred for $1.5 \mathrm{~h}$ at room temperature, quenched with $\mathrm{H}_{2} \mathrm{O}$ and the aqueous phase was extracted with EtOAc. The combined organic extracts were dried over anhydrous $\mathrm{Na}_{2} \mathrm{SO}_{4}$ and concentrated under reduced pressure. Flash column chromatography (70:1 hexane/EtOAc) afforded (E)-6-((tert-butyldimethylsilyl)oxy)-3-methylhex-2-en-1-yl acetate (A) (1.80 g, quant.) as a colorless oil: IR (neat) 3055, 1731, 1423, 1265, $741 \mathrm{~cm}^{-1}$; ${ }^{1} \mathrm{H}-\mathrm{NMR}(300 \mathrm{MHz}$, $\left.\mathrm{CDCl}_{3}\right) \delta 5.28-5.24(\mathrm{~m}, 1 \mathrm{H}), 4.48(\mathrm{~d}, J=7.4 \mathrm{~Hz}, 2 \mathrm{H}), 3.50(\mathrm{t}, J=6.5 \mathrm{~Hz}, 2 \mathrm{H})$, $2.00(\mathrm{t}, J=7.5 \mathrm{~Hz}, 2 \mathrm{H}), 1.94(\mathrm{~s}, 3 \mathrm{H}), 1.61(\mathrm{~s}, 3 \mathrm{H}), 1.58-1.51(\mathrm{~m}, 2 \mathrm{H}), 0.80$ (s, 9H), $-0.05(\mathrm{~s}, 6 \mathrm{H}) ;{ }^{13} \mathrm{C}-\mathrm{NMR}\left(100 \mathrm{MHz}, \mathrm{CDCl}_{3}\right) \delta 170.1,141.7,118.4$, $62.3,59.1,35.6,30.6,26.0,20.8,18.2,16.2,-5.4$; HRMS (FAB, $m$-NBA) [M $+\mathrm{H}]^{+}$calcd for $\mathrm{C}_{15} \mathrm{H}_{31} \mathrm{O}_{3} \mathrm{Si} 287.2029$, found 287.2024.

To a solution of $\mathbf{A}(3.49 \mathrm{~g}, 12.2 \mathrm{mmol})$ in $\mathrm{MeOH}(61 \mathrm{ml})$ at $0{ }^{\circ} \mathrm{C}$ was added aqueous $\mathrm{K}_{2} \mathrm{CO}_{3}(60 \mathrm{ml}, 0.2 \mathrm{M})$. The mixture was stirred for $3 \mathrm{~h}$ at room temperature, diluted with $\mathrm{H}_{2} \mathrm{O}$ and the aqueous phase was extracted with $\mathrm{CH}_{2} \mathrm{Cl}_{2}$. The combined organic extracts were dried over anhydrous $\mathrm{Na}_{2} \mathrm{SO}_{4}$ and concentrated under reduced pressure. Flash column chromatography (10:1 hexane/EtOAc) afforded (E)-6-((tert-butyldimethylsilyl)oxy)-3-methylhex-2-en-1-ol (B) $(2.98 \mathrm{~g}, 97 \%)$ as a colorless oil: IR (neat) 3445, 2953, 2857, 2360, 1265, 1097, $743 \mathrm{~cm}^{-1}$; ${ }^{1} \mathrm{H}-\mathrm{NMR}\left(300 \mathrm{MHz}, \mathrm{CDCl}_{3}\right) \delta 5.41-5.37$ $(\mathrm{m}, 1 \mathrm{H}), 4.11(\mathrm{~d}, J=6.6 \mathrm{~Hz}, 2 \mathrm{H}), 3.58(\mathrm{t}, J=6.4 \mathrm{~Hz}, 2 \mathrm{H}), 2.03(\mathrm{t}, J=7.7 \mathrm{~Hz}$, $2 \mathrm{H}), 1.65(\mathrm{~s}, 3 \mathrm{H}), 1.65-1.58(\mathrm{~m}, 2 \mathrm{H}), 0.87(\mathrm{~s}, 9 \mathrm{H}), 0.023(\mathrm{~s}, 6 \mathrm{H}) ;{ }^{13} \mathrm{C}-\mathrm{NMR}$ $\left(100 \mathrm{MHz}, \mathrm{CDCl}_{3}\right) \delta 139.3,123.4,62.7,59.2,35.7,30.9,25.0,18.3,16.2,-5.3$; HRMS (FAB, m-NBA) $[\mathrm{M}+\mathrm{H}]^{+}$calcd for $\mathrm{C}_{13} \mathrm{H}_{29} \mathrm{O}_{2} \mathrm{Si}$ 245.1927, found 245.1931.

A mixture of $\mathrm{Ti}(\mathrm{OiPr})_{4}(3.60 \mathrm{ml}, 12.2 \mathrm{mmol})$ and $4 \AA$ molecular sieves $(1.19 \mathrm{~g})$ in $\mathrm{CH}_{2} \mathrm{Cl}_{2}(76 \mathrm{ml})$ was treated with $(-)$-DET $(2.09 \mathrm{ml}, 12.2 \mathrm{mmol})$, and the resulting solution was vigorously stirred at $-5^{\circ} \mathrm{C}$ for $1 \mathrm{~h}$. tert-Butyl hydroperoxide $(5.0-6.0 \mathrm{M}$ in decane, $4.88 \mathrm{ml}, 24.4 \mathrm{mmol}$ ) was slowly added to the mixture, and the solution was stirred at $-20^{\circ} \mathrm{C}$ for $1 \mathrm{~h}$. A solution of B $(2.98 \mathrm{~g}, 12.2 \mathrm{mmol})$ in $\mathrm{CH}_{2} \mathrm{Cl}_{2}(46 \mathrm{ml})$ was added to the above mixture, and the solution was stirred at $-20{ }^{\circ} \mathrm{C}$ for $1.5 \mathrm{~h}$. After $\mathrm{Me}_{2} \mathrm{~S}(1.34 \mathrm{ml}, 18.3 \mathrm{mmol})$ was added, the mixture was further stirred at $-20^{\circ} \mathrm{C}$ for $1 \mathrm{~h}$. The resulting mixture was diluted with $\mathrm{CH}_{2} \mathrm{Cl}_{2}$, treated with celite $(6.00 \mathrm{~g})$ and $\mathrm{Na}_{2} \mathrm{SO}_{4} \cdot 10 \mathrm{H}_{2} \mathrm{O}(6.00 \mathrm{~g})$, and subsequently stirred for $2 \mathrm{~h}$ at room temperature. The resulting suspension was filtered through a pad of celite, and the filtrate was concentrated under reduced pressure. The residue was purified by silica gel flash column chromatography (5:1 hexane/EtOAc) to afford $10(2.70 \mathrm{~g}, 90 \%)$ as a colorless oil: $[\alpha]^{23} \mathrm{D}+4.26\left(c 1.00, \mathrm{CHCl}_{3}\right)$; IR (neat) $3434,3021,1216$, $769 \mathrm{~cm}^{-1}$; ${ }^{1} \mathrm{H}-\mathrm{NMR}\left(400 \mathrm{MHz}, \mathrm{CDCl}_{3}\right) \delta 3.83-3.80(\mathrm{~m}, 1 \mathrm{H}), \quad 3.73-3.70$ $(\mathrm{m}, 1 \mathrm{H}), 3.63-3.59(\mathrm{~m}, 2 \mathrm{H}), 2.70(\mathrm{dd}, J=6.7,4.3 \mathrm{~Hz}, 1 \mathrm{H}), 1.67-1.52$ $(\mathrm{m}, 4 \mathrm{H}), 1.30(\mathrm{~s}, 3 \mathrm{H}), 0.88(\mathrm{~s}, 9 \mathrm{H}), 0.039(\mathrm{~s}, 6 \mathrm{H}) ;{ }^{13} \mathrm{C}-\mathrm{NMR}(100 \mathrm{MHz}$, $\left.\mathrm{CDCl}_{3}\right) \delta 62.9,62.7,61.3,61.2,34.9,28.3,26.0,25.9,25.8,18.3,16.8,-5.3$, - 5.4; HRMS (FAB, $m$-NBA) $[\mathrm{M}+\mathrm{H}]^{+}$calcd for $\mathrm{C}_{13} \mathrm{H}_{29} \mathrm{O}_{3} \mathrm{Si} 261.1883$, found 261.1886 .
tert-Butyl(3-((2R,3S)-3-(iodomethyl)-2-methyloxiran-2-yl)propoxy) dimethylsilane (11)

To a solution of $10(2.70 \mathrm{~g}, 10.4 \mathrm{mmol})$ in $\mathrm{CH}_{2} \mathrm{Cl}_{2}(100 \mathrm{ml})$ at $0{ }^{\circ} \mathrm{C}$ were added imidazole $(2.04 \mathrm{~g}, 31.1 \mathrm{mmol}), \mathrm{PPh}_{3}(4.08 \mathrm{~g}, 15.6 \mathrm{mmol})$ and $\mathrm{I}_{2}(3.95 \mathrm{~g}$, $15.6 \mathrm{mmol}$ ). The mixture was stirred for $50 \mathrm{~min}$ at $0{ }^{\circ} \mathrm{C}$, quenched with saturated aqueous $\mathrm{Na}_{2} \mathrm{~S}_{2} \mathrm{O}_{3}$ and the aqueous phase was extracted with EtOAc. The combined organic extracts were dried over anhydrous $\mathrm{Na}_{2} \mathrm{SO}_{4}$ and concentrated under reduced pressure. Flash column chromatography (30:1 hexane/EtOAc) afforded $11(3.66 \mathrm{~g}, 95 \%)$ as a colorless oil: $[\alpha]^{30} \mathrm{D}$ - 32.0 ( c 1.00, $\mathrm{CHCl}_{3}$ ); IR (neat) 2953, 2857, 1253, 1101, 776, 616, $474 \mathrm{~cm}^{-1}$; ${ }^{1} \mathrm{H}-\mathrm{NMR}\left(400 \mathrm{MHz}, \mathrm{CDCl}_{3}\right) \delta 3.62-3.59(\mathrm{td}, J=6.2,2.3 \mathrm{~Hz}, 2 \mathrm{H}), 3.34$ (dd, $J=9.7,5.5 \mathrm{~Hz}, 1 \mathrm{H}), 3.07$ (dd, $J=8.6,5.5 \mathrm{~Hz}, 1 \mathrm{H}), 2.97$ (dd, $J=9.7$, $8.6 \mathrm{~Hz}, 1 \mathrm{H}), 1.68-1.60(\mathrm{~m}, 3 \mathrm{H}), 1.58-1.48(\mathrm{~m}, 1 \mathrm{H}), 1.26(\mathrm{~s}, 3 \mathrm{H}), 0.87(\mathrm{~s}, 9 \mathrm{H})$, $0.031(\mathrm{~s}, 6 \mathrm{H}) ;{ }^{13} \mathrm{C}-\mathrm{NMR}\left(100 \mathrm{MHz}, \mathrm{CDCl}_{3}\right) \delta 63.9,62.7,62.4,34.7,28.5,26.0$, $18.3,15.7,2.4,-5.3$; HRMS (FAB, $m$-NBA) $[\mathrm{M}+\mathrm{H}]^{+}$calcd for $\mathrm{C}_{13} \mathrm{H}_{28} \mathrm{O}_{2} \mathrm{SiI}$ 371.0915, found 371.0903 .

\section{((3-Methylbut-2-en-1-yl)sulfonyl)benzene (12)}

To a solution of 1-bromo-3-methyl-2-butene $(100 \mu \mathrm{l}, 0.859 \mathrm{mmol})$ in dimethylformamide $(8.6 \mathrm{ml})$ at room temperature were added $\mathrm{PhSO}_{2} \mathrm{Na}$ $(169 \mathrm{mg}, 1.03 \mathrm{mmol})$ and $\mathrm{Bu}_{4} \mathrm{NI}(3.2 \mathrm{mg}, 0.00859 \mathrm{mmol})$. The mixture was stirred for $1 \mathrm{~h}$ at room temperature, quenched with $\mathrm{H}_{2} \mathrm{O}$, and the aqueous phase was extracted with EtOAc. The combined organic extracts were dried over anhydrous $\mathrm{Na}_{2} \mathrm{SO}_{4}$ and concentrated under reduced pressure. Flash column chromatography (10:1 hexane/EtOAc) afforded 12 (ref. 11; $115 \mathrm{mg}$, $82 \%)$ as a colorless oil: ${ }^{1} \mathrm{H}-\mathrm{NMR}\left(400 \mathrm{MHz}, \mathrm{CDCl}_{3}\right) \delta 7.86-7.83(\mathrm{~m}, 2 \mathrm{H})$, 7.62-7.60 (m, 1H), 7.54-7.50 (m, 2H), 5.21-5.15 (m, $1 \mathrm{H}), 3.76(\mathrm{~d}, J=7.8 \mathrm{~Hz}$, $2 \mathrm{H}), 1.69(\mathrm{~s}, 3 \mathrm{H}), 1.30(\mathrm{~s}, 3 \mathrm{H})$

(tert-Butyldimethyl(3-((2R,3R)-2-methyl-3-(4-methylpent-3-en-1-yl) oxiran-2-yl)propoxy)silane (15)

To a solution of $12(200 \mathrm{mg}, 0.540 \mathrm{mmol})$ in THF $(4.0 \mathrm{ml})$ at $-78^{\circ} \mathrm{C}$ were added hexamethylphosphoramide $(391 \mu \mathrm{l}, 2.25 \mathrm{mmol})$ and $n$-BuLi $(1.64 \mathrm{M}$ in $n$-hexane, $550 \mu \mathrm{l}, 0.900 \mathrm{mmol}$ ). After stirring for $1 \mathrm{~h}$ at $-78^{\circ} \mathrm{C}$, a solution of 11 (94.6 mg, $0.450 \mathrm{mmol})$ in THF $(2.0 \mathrm{ml})$ was added dropwise to the above mixture. The resulting mixture was stirred for $15 \mathrm{~min}$ at $-78^{\circ} \mathrm{C}$, quenched with saturated aqueous $\mathrm{NH}_{4} \mathrm{Cl}$ and the aqueous phase was extracted with EtOAc. The combined organic extracts were dried over anhydrous $\mathrm{Na}_{2} \mathrm{SO}_{4}$ and concentrated under reduced pressure. The residue was briefly purified by flash column chromatography (10:1 hexane/EtOAc) to afford the corresponding coupling product, which was dissolved in DMSO $(4.2 \mathrm{ml})$ and treated with Pd $(\mathrm{OAc})_{2}(24.2 \mathrm{mg}, 0.108 \mathrm{mmol})$ and dppp $(55.7 \mathrm{mg}, 0.135 \mathrm{mmol})$. After stirring for $15 \mathrm{~min}$ at room temperature, $\mathrm{NaBH}_{4}(24.5 \mathrm{mg}, 0.648 \mathrm{mmol})$ was added to the mixture. The resulting mixture was stirred for $20 \mathrm{~min}$ at room temperature, quenched with $\mathrm{H}_{2} \mathrm{O}$ and the aqueous phase was extracted with EtOAc. The combined organic extracts were dried over anhydrous $\mathrm{Na}_{2} \mathrm{SO}_{4}$ and concentrated under reduced pressure. Flash column chromatography (50:1 hexane/ EtOAc) afforded $15(107 \mathrm{mg}, 2$ steps, $76 \%)$ as a colorless oil: $[\alpha]^{30}{ }_{\mathrm{D}}-58.1$ (c 1.00, $\mathrm{CHCl}_{3}$ ); IR (neat) $3000,1635,1275,1261,750 \mathrm{~cm}^{-1} ;{ }^{1} \mathrm{H}-\mathrm{NMR}$ $\left(400 \mathrm{MHz}, \quad \mathrm{CDCl}_{3}\right) \delta 5.12(\mathrm{t}, \quad J=2.0 \mathrm{~Hz}, 1 \mathrm{H}), \quad 3.60-3.56 \quad(\mathrm{~m}, \quad 2 \mathrm{H})$, $2.69(\mathrm{t}, J=6.3 \mathrm{~Hz}, 1 \mathrm{H}), 2.15-2.09(\mathrm{~m}, 2 \mathrm{H}), 1.68(\mathrm{~s}, 3 \mathrm{H}), 1.63-1.44(\mathrm{~m}, 6 \mathrm{H})$, $1.59(\mathrm{~s}, 3 \mathrm{H}), 1.23(\mathrm{~s}, 3 \mathrm{H}), 0.88(\mathrm{~s}, 9 \mathrm{H}), 0.022(\mathrm{~s}, 6 \mathrm{H}) ;{ }^{13} \mathrm{C}-\mathrm{NMR}(100 \mathrm{MHz}$, $\left.\mathrm{CDCl}_{3}\right) \delta 132.3,123.4,63.2,62.9,60.8,35.1,28.9,28.5,25.9,25.7,25.0,18.3$, 17.6, 16.6, -5.3; HRMS (FAB, $m$-NBA) $[\mathrm{M}+\mathrm{H}]^{+}$calcd for $\mathrm{C}_{18} \mathrm{H}_{37} \mathrm{O}_{2} \mathrm{Si}$ 313.2554, found 313.2563 .

(R)-5-Methyl-1-((S)-2-methyltetrahydrofuran-2-yl)hex-4-en-1-ol (4) To a solution of $15(81.3 \mathrm{mg}, 0.270 \mathrm{mmol})$ in THF $(2.7 \mathrm{ml})$ at room temperature was added tetrabutylammonium fluoride $(1.0 \mathrm{M}$ in THF, $5.4 \mathrm{ml}$, $0.540 \mathrm{mmol}$ ). After stirring for $1 \mathrm{~h}$ at room temperature, the resulting mixture was quenched with $\mathrm{H}_{2} \mathrm{O}$ and the aqueous phase was extracted with EtOAc. The combined organic extracts were dried over anhydrous $\mathrm{Na}_{2} \mathrm{SO}_{4}$ and concentrated under reduced pressure. This residue was employed in the next reaction without further purification. The residue was dissolved in $\mathrm{CH}_{2} \mathrm{Cl}_{2}(2.7 \mathrm{ml})$ and treated with pyridinium $p$-toluenesulfonate $(3.4 \mathrm{mg}, 0.0135 \mathrm{mmol})$. After stirring for $30 \mathrm{~min}$ at room temperature, the reaction was quenched with 
brine and the aqueous phase was extracted with EtOAc. The combined organic extracts were dried over anhydrous $\mathrm{Na}_{2} \mathrm{SO}_{4}$ and concentrated under reduced pressure. Flash column chromatography (25:1 hexane/EtOAc) afforded 4 (147 mg, 2 steps, $97 \%)$ as a colorless oil: $[\alpha]^{30} \mathrm{D}+32.6\left(c 1.00, \mathrm{CHCl}_{3}\right)$; IR (neat) $3435,2349,1635,1260,1051,750 \mathrm{~cm}^{-1}$; ${ }^{1} \mathrm{H}-\mathrm{NMR}\left(400 \mathrm{MHz}, \mathrm{CDCl}_{3}\right) \delta$ 5.15-5.11 (m, 1H), 3.91-3.80 (m, 2H), 3.53 (dd, $J=10.5,2.1 \mathrm{~Hz}, 1 \mathrm{H}), 2.36$ (brs, $1 \mathrm{H}), 2.28-2.22(\mathrm{~m}, 1 \mathrm{H}), 2.17-2.07(\mathrm{~m}, 1 \mathrm{H}), 2.05-1.89(\mathrm{~m}, 3 \mathrm{H}), 1.69$ $(\mathrm{s}, 3 \mathrm{H}), 1.63(\mathrm{~s}, 3 \mathrm{H}), 1.50-1.42(\mathrm{~m}, 2 \mathrm{H}), 1.38-1.30(\mathrm{~m}, 1 \mathrm{H}), 1.11(\mathrm{~s}, 3 \mathrm{H})$; ${ }^{13} \mathrm{C}-\mathrm{NMR}\left(100 \mathrm{MHz}, \mathrm{CDCl}_{3}\right) \delta 132.0,124.2,85.8,76.0,67.9,31.9,30.6,26.3$, $25.7,25.2,23.1,17.7$; HRMS (FAB, $m$-NBA) $[\mathrm{M}+\mathrm{H}]^{+}$calcd for $\mathrm{C}_{12} \mathrm{H}_{23} \mathrm{O}_{2}$ 199.1698, found 199.1698.

\section{(E)-((3,7-Dimethylocta-2,6-dien-1-yl)sulfonyl)benzene (13)}

To a solution of geraniol $(200 \mu \mathrm{l}, 1.14 \mathrm{mmol})$ in $\mathrm{Et}_{2} \mathrm{O}(11 \mathrm{ml})$ at $0{ }^{\circ} \mathrm{C}$ was added $\mathrm{PBr}_{3}(53 \mu \mathrm{l}, 0.570 \mathrm{mmol})$. After stirring for $1.5 \mathrm{~h}$ at $0{ }^{\circ} \mathrm{C}$, the resulting mixture was quenched with cold water and the aqueous phase was extracted with a 1:1 $\mathrm{Et}_{2} \mathrm{O}$ :hexane mixture. The combined organic extracts were dried over anhydrous $\mathrm{Na}_{2} \mathrm{SO}_{4}$ and concentrated under reduced pressure. This residue was employed in the next reaction without further purification. The residue was dissolved in DMF $(11 \mathrm{ml})$ and treated with $\mathrm{Bu}_{4} \mathrm{NI}(4.2 \mathrm{mg}, 0.0114 \mathrm{mmol})$ and $\mathrm{PhSO}_{2} \mathrm{Na}(224 \mathrm{mg}, 1.37 \mathrm{mmol})$. After stirring for $1.5 \mathrm{~h}$ at room temperature, the reaction was quenched with $\mathrm{H}_{2} \mathrm{O}$ and the aqueous phase was extracted with EtOAc. The combined organic extracts were dried over anhydrous $\mathrm{Na}_{2} \mathrm{SO}_{4}$ and concentrated under reduced pressure. Flash column chromatography (30:1 hexane/EtOAc) afforded 13 (ref. 11; $279 \mathrm{mg}, 2$ steps, 88\%) as a colorless oil: ${ }^{1} \mathrm{H}-\mathrm{NMR}\left(400 \mathrm{MHz}, \mathrm{CDCl}_{3}\right) \delta$ 7.88-7.85 (m, 2H), 7.65-7.61 (m, $\left.1 \mathrm{H}\right)$, 7.55-7.51 (m, 2H), $5.23(\mathrm{dt}, J=7.8,1.0 \mathrm{~Hz}, 1 \mathrm{H}), 5.03-5.00(\mathrm{~m}, 1 \mathrm{H})$, $3.80(\mathrm{~d}, J=7.8 \mathrm{~Hz}, 2 \mathrm{H}), 2.00-1.99(\mathrm{~m}, 4 \mathrm{H}), 1.68(\mathrm{~s}, 3 \mathrm{H}), 1.58(\mathrm{~s}, 3 \mathrm{H}), 1.31$ (s, 3H).

\section{tert-Butyl(3-((2R,3R)-3-((E)-4,8-dimethylnona-3,7-dien-1-yl)-2-} methyloxiran-2-yl)propoxy)dimethylsilane (16)

To a solution of $13(147 \mathrm{mg}, 0.530 \mathrm{mmol})$ in THF $(7.9 \mathrm{ml})$ at $-78^{\circ} \mathrm{C}$ were added hexamethylphosphoramide $(460 \mu \mathrm{l}, 2.65 \mathrm{mmol})$ and $n$-BuLi $(1.64 \mathrm{M}$ in $n$-hexane, $646 \mu \mathrm{l}, 1.06 \mathrm{mmol})$. After stirring for $1 \mathrm{~h}$ at $-78^{\circ} \mathrm{C}$, a solution of $11(291 \mathrm{mg}, 0.790 \mathrm{mmol})$ in THF $(3.0 \mathrm{ml})$ was added dropwise to the above mixture. The resulting mixture was stirred for $30 \mathrm{~min}$ at $-78^{\circ} \mathrm{C}$, quenched with saturated aqueous $\mathrm{NH}_{4} \mathrm{Cl}$ and the aqueous phase was extracted with EtOAc. The combined organic extracts were dried over anhydrous $\mathrm{Na}_{2} \mathrm{SO}_{4}$ and concentrated under reduced pressure. The residue was briefly purified by flash column chromatography (20:1 hexane/EtOAc) to afford the corresponding coupling product, which was dissolved in DMSO $(4.8 \mathrm{ml})$ and treated with Pd $(\mathrm{OAc})_{2}(25.9 \mathrm{mg}, 0.106 \mathrm{mmol})$ and dppp $(54.6 \mathrm{mg}, 0.133 \mathrm{mmol})$. After stirring for $15 \mathrm{~min}$ at room temperature, $\mathrm{NaBH}_{4}(40.1 \mathrm{mg}, 1.06 \mathrm{mmol})$ was added to the mixture. The reaction was stirred for $20 \mathrm{~min}$ at room temperature, quenched with $\mathrm{H}_{2} \mathrm{O}$ and the aqueous phase was extracted with EtOAc. The combined organic extracts were dried over anhydrous $\mathrm{Na}_{2} \mathrm{SO}_{4}$ and concentrated under reduced pressure. Flash column chromatography (40:1 hexane/ EtOAc) afforded $16(129 \mathrm{mg}, 2$ steps, $73 \%)$ as a colorless oil: $[\alpha]^{23} \mathrm{D}+2.77$ (c 1.00, $\mathrm{CHCl}_{3}$ ); IR (neat) 3055, 2986, 1636, 1422, 1265, $749 \mathrm{~cm}^{-1}$; ${ }^{1} \mathrm{H}-\mathrm{NMR}$ $\left(400 \mathrm{MHz}, \mathrm{CDCl}_{3}\right) \delta 5.14(\mathrm{dd}, J=7.0,1.2 \mathrm{~Hz}, 1 \mathrm{H}), 5.07(\mathrm{dt}, J=7.0,1.6 \mathrm{~Hz}$, $1 \mathrm{H}), 3.60-3.56(\mathrm{~m}, 2 \mathrm{H}), 2.70(\mathrm{t}, J=6.3 \mathrm{~Hz}, 1 \mathrm{H}), 2.20-1.95(\mathrm{~m}, 6 \mathrm{H}), 1.66$ $(\mathrm{s}, 3 \mathrm{H}), 1.66-1.44(\mathrm{~m}, 6 \mathrm{H}), 1.58(\mathrm{~s}, 3 \mathrm{H}), 1.54(\mathrm{~s}, 3 \mathrm{H}), 1.23(\mathrm{~s}, 3 \mathrm{H}), 0.87(\mathrm{~s}, 9 \mathrm{H})$, $0.02(\mathrm{~s}, 6 \mathrm{H}) ;{ }^{13} \mathrm{C}-\mathrm{NMR}\left(100 \mathrm{MHz}, \mathrm{CDCl}_{3}\right) \delta 135.9,131.3,124.2,123.2,63.2$, $62.9,60.8,39.7,35.1,28.9,28.6,26.6,25.9,25.7,25.6,24.8,18.2,17.7,16.6$, 16.0, - 5.3; HRMS (EI) $[\mathrm{M}]^{+}$calcd for $\mathrm{C}_{23} \mathrm{H}_{44} \mathrm{O}_{2} \mathrm{Si} 380.3113$, found 380.3111 .

\section{$(R, E)-5,9-D i m e t h y l-1-((S)-2-m e t h y l t e t r a h y d r o f u r a n-2-y l) d e c a-4$, 8-dien-1-ol (5)}

To a solution of 16 (243 mg, $0.70 \mathrm{mmol})$ in THF $(7.0 \mathrm{ml})$ at room temperature was added tetrabutylammonium fluoride ( $1.0 \mathrm{M}$ in THF, $1.40 \mathrm{ml}, 1.40 \mathrm{mmol})$. After stirring for $1 \mathrm{~h}$ at room temperature, the resulting mixture was quenched with brine and the aqueous phase was extracted with EtOAc. The combined organic extracts were dried over anhydrous $\mathrm{Na}_{2} \mathrm{SO}_{4}$ and concentrated under reduced pressure. This residue was employed in the next reaction without further purification. The residue was dissolved in $\mathrm{CH}_{2} \mathrm{Cl}_{2}(7.0 \mathrm{ml})$ and treated with pyridinium $p$-toluenesulfonate $(8.8 \mathrm{mg}, 0.035 \mathrm{mmol})$. After stirring for $1.5 \mathrm{~h}$ at room temperature, the reaction was quenched with $\mathrm{H}_{2} \mathrm{O}$ and the aqueous phase was extracted with EtOAc. The combined organic extracts were dried over anhydrous $\mathrm{Na}_{2} \mathrm{SO}_{4}$ and concentrated under reduced pressure. Flash column chromatography (20:1 hexane/EtOAc) afforded $\mathbf{5}$ (175 mg, 2 steps, $94 \%)$ as a colorless oil: $[\alpha]^{30} \mathrm{D}+4.62$ (c 1.00, $\mathrm{CHCl}_{3}$ ); IR (neat) $3452,3055,1636,1422,1265,750 \mathrm{~cm}^{-1} ;{ }^{1} \mathrm{H}-\mathrm{NMR}(400 \mathrm{MHz}$, $\left.\mathrm{CDCl}_{3}\right) \delta$ 5.16-5.07 (m, 2H), 3.91-3.80 (m, $\left.2 \mathrm{H}\right), 3.59(\mathrm{dd}, J=10.0,2.0 \mathrm{~Hz}$, $1 \mathrm{H}), 2.35$ (brs, $1 \mathrm{H}), 2.29-2.21(\mathrm{~m}, 1 \mathrm{H}), 2.17-1.88(\mathrm{~m}, 8 \mathrm{H}), 1.67(\mathrm{~s}, 3 \mathrm{H})$, $1.63(\mathrm{~s}, 3 \mathrm{H}), 1.59$ (s, 3H), 1.51-1.43 (m, 2H), 1.40-1.30 (m, 1H), $1.11(\mathrm{~s}, 3 \mathrm{H})$; ${ }^{13} \mathrm{C}-\mathrm{NMR}\left(100 \mathrm{MHz}, \mathrm{CDCl}_{3}\right) \delta 135.7,131.3,124.3,124.0,85.7,76.0,67.9$, $39.7,31.9,30.6,26.7,26.3,25.7,25.0,23.1,17.7,16$; HRMS (FAB m-NBA) $[\mathrm{M}+\mathrm{H}]^{+}$calcd for $\mathrm{C}_{17} \mathrm{H}_{31} \mathrm{O}_{2}$ 267.2327, found 267.2324.

\section{(((2E,6E,10E)-3,7,11,15-Tetramethylhexadeca-2,6,10,14-tetraen-1-yl)} sulfonyl)benzene (14)

To a solution of geranyl geraniol $(43.1 \mathrm{mg}, 0.148 \mathrm{mmol})$ in $\mathrm{Et}_{2} \mathrm{O}(3.0 \mathrm{ml})$ at $0{ }^{\circ} \mathrm{C}$ was added $\mathrm{PBr}_{3}(7 \mu \mathrm{l}, 0.0742 \mathrm{mmol})$. After stirring for $2 \mathrm{~h}$ at $0{ }^{\circ} \mathrm{C}$, the resulting mixture was quenched with cold water and the aqueous phase was extracted with a 1:1 $\mathrm{Et}_{2} \mathrm{O}$ :hexane mixture. The combined organic extracts were dried over anhydrous $\mathrm{Na}_{2} \mathrm{SO}_{4}$ and concentrated under reduced pressure. This residue was employed in the next reaction without further purification. The residue was dissolved in DMF $(3.0 \mathrm{ml})$ and treated with $\mathrm{Bu}_{4} \mathrm{NI}(0.5 \mathrm{mg}$, $0.0015 \mathrm{mmol}$ ) and $\mathrm{PhSO}_{2} \mathrm{Na}(29.2 \mathrm{mg}, 0.178 \mathrm{mmol})$. After stirring for $3 \mathrm{~h}$ at room temperature, the reaction was quenched with $\mathrm{H}_{2} \mathrm{O}$ and the aqueous phase was extracted with EtOAc. The combined organic extracts were dried over anhydrous $\mathrm{Na}_{2} \mathrm{SO}_{4}$ and concentrated under reduced pressure. Flash column chromatography (70:1 hexanes/EtOAc) afforded 14 (ref. 12; $38.0 \mathrm{mg}, 2$ steps, $63 \%)$ as a colorless oil: ${ }^{1} \mathrm{H}-\mathrm{NMR}\left(400 \mathrm{MHz}, \mathrm{CDCl}_{3}\right) \delta 7.88-7.85(\mathrm{~m}, 2 \mathrm{H})$, 7.65-7.61 (m, 1H), 7.55-7.30 (m, 2H), 5.19 (dt, J=8.2, 1.2 Hz, 1H), 5.11-5.03 (m, 3H), 3.80 (d, J=8.2 Hz, 2H), 2.09-1.92 (m, 12H), 1.67 (s, 3H), 1.65-1.58 $(\mathrm{m}, 9 \mathrm{H}), 1.25(\mathrm{~s}, 3 \mathrm{H})$.

\section{tert-Butyldimethyl(3-((2R,3R)-2-methyl-3-((3E,7E,11E)-4,8,12,16- tetramethylheptadeca-3,7,11,15-tetraen-1-yl)oxiran-2-yl)propoxy)} silane (17)

To a solution of $\mathbf{1 4}(32.0 \mathrm{mg}, 0.0772 \mathrm{mmol})$ in THF $(2.0 \mathrm{ml})$ at $-78^{\circ} \mathrm{C}$ were added hexamethylphosphoramide $(67 \mu \mathrm{l}, 0.386 \mathrm{mmol})$ and $n$-BuLi $(1.64 \mathrm{M}$ in $n$-hexane, $57 \mu \mathrm{l}, 0.0926 \mathrm{mmol})$. After stirring for $1 \mathrm{~h}$ at $-78^{\circ} \mathrm{C}$, a solution of $11(291 \mathrm{mg}, 0.790 \mathrm{mmol})$ in THF $(3.0 \mathrm{ml})$ was added dropwise to the above mixture. The resulting mixture was stirred for $30 \mathrm{~min}$ at $-78^{\circ} \mathrm{C}$, quenched with saturated aqueous $\mathrm{NH}_{4} \mathrm{Cl}$ and the aqueous phase was extracted with EtOAc. The combined organic extracts were dried over anhydrous $\mathrm{Na}_{2} \mathrm{SO}_{4}$ and concentrated under reduced pressure. The residue was purified briefly by flash column chromatography (10:1 hexane/EtOAc) to afford the corresponding coupling product, which was dissolved in DMSO $(1.0 \mathrm{ml})$ and treated with Pd $(\mathrm{OAc})_{2}(3.7 \mathrm{mg}, 0.154 \mathrm{mmol})$ and dppp $(7.9 \mathrm{mg}, 0.0193 \mathrm{mmol})$. After stirring for $15 \mathrm{~min}$ at room temperature, $\mathrm{NaBH}_{4}(3.5 \mathrm{mg}, 0.0926 \mathrm{mmol})$ was added to the mixture. The reaction was stirred for $30 \mathrm{~min}$ at room temperature, quenched with $\mathrm{H}_{2} \mathrm{O}$ and the aqueous phase was extracted with EtOAc. The combined organic extracts were dried over anhydrous $\mathrm{Na}_{2} \mathrm{SO}_{4}$ and concentrated under reduced pressure. Flash column chromatography (40:1 hexane/ EtOAc) afforded $17(10.8 \mathrm{mg}, 2$ steps, $27 \%)$ as a colorless oil: $[\alpha]^{30}{ }_{\mathrm{D}}+0.93$ (c 1.00, $\mathrm{CHCl}_{3}$ ); IR (neat) 3054, 2986, 1635, 1423, 1265, $748 \mathrm{~cm}^{-1}$; ${ }^{1} \mathrm{H}-\mathrm{NMR}$ $\left(400 \mathrm{MHz}, \mathrm{CDCl}_{3}\right) \delta 5.15-5.09(\mathrm{~m}, 4 \mathrm{H}), 3.62-3.58(\mathrm{~m}, 2 \mathrm{H}), 2.71(\mathrm{t}, J=6.2 \mathrm{~Hz}$ $1 \mathrm{H}), 2.16-2.00(\mathrm{~m}, 14 \mathrm{H}), 1.68(\mathrm{~s}, 3 \mathrm{H}), 1.65-1.46(\mathrm{~m}, 6 \mathrm{H}), 1.62-1.58(\mathrm{~m}, 12 \mathrm{H})$, $1.24(\mathrm{~s}, 3 \mathrm{H}), 0.88(\mathrm{~s}, 9 \mathrm{H}), 0.04(\mathrm{~s}, 6 \mathrm{H}) ;{ }^{13} \mathrm{C}-\mathrm{NMR}\left(100 \mathrm{MHz}, \mathrm{CDCl}_{3}\right) \delta 135.9$, $135.1,134.9,131.4,124.4,124.2,124.1,123.2,63.2,62.9,60.8,39.7,35.1,28.9$, 28.5, 26.8, 26.6, 25.9, 25.7, 25.6, 24.9, 18.3, 17.7, 16.6, 16.0, - 5.3; HRMS (EI) $[\mathrm{M}]^{+}$calcd for $\mathrm{C}_{33} \mathrm{H}_{60} \mathrm{O}_{2} \mathrm{Si}$ 516.4366, found 516.4363 .

\section{$(R, 4 E, 8 E, 12 E)-5,9,13,17-T e t r a m e t h y l-1-((S)-2-m e t h y l t e t r a-$ hydrofuran-2-yl)octadeca-4,8,12,16-tetraen-1-ol (6)}

To a solution of $17(9.0 \mathrm{mg}, 0.0174 \mathrm{mmol})$ in THF $(1.7 \mathrm{ml})$ at room temperature was added tetrabutylammonium fluoride $(1.0 \mathrm{M}$ in THF, $35 \mu \mathrm{l}$, 
$0.0348 \mathrm{mmol}$ ). After stirring for $1 \mathrm{~h}$ at room temperature, the resulting mixture was quenched with brine and the aqueous phase was extracted with EtOAc. The combined organic extracts were dried over anhydrous $\mathrm{Na}_{2} \mathrm{SO}_{4}$ and concentrated under reduced pressure. This residue was employed in the next reaction without further purification. The residue was dissolved in $\mathrm{CH}_{2} \mathrm{Cl}_{2}(500 \mu \mathrm{l})$ and treated with pyridinium $p$-toluenesulfonate $(0.1 \mathrm{mg}, 0.00085 \mathrm{mmol})$. After stirring for $1 \mathrm{~h}$ at room temperature, the reaction was quenched with $\mathrm{H}_{2} \mathrm{O}$ and the aqueous phase was extracted with EtOAc. The combined organic extracts were dried over anhydrous $\mathrm{Na}_{2} \mathrm{SO}_{4}$ and concentrated under reduced pressure. Flash column chromatography (8:1 hexane/EtOAc) afforded 6 (5.0 mg, 2 steps, $71 \%)$ as a colorless oil: $[\alpha]^{28}-9.7$ (c 1.00, $\mathrm{CHCl}_{3}$ ); IR (neat) 3441, 3056, 2987, 1634, 1424, 1266, $752 \mathrm{~cm}^{-1}$; ${ }^{1} \mathrm{H}-\mathrm{NMR}(400 \mathrm{MHz}$, $\left.\mathrm{CDCl}_{3}\right) \delta 5.16-5.07(\mathrm{~m}, 4 \mathrm{H}), 3.91-3.80(\mathrm{~m}, 2 \mathrm{H}), 3.53(\mathrm{dd}, J=10.1,1.7 \mathrm{~Hz}$, $1 \mathrm{H}), 2.35$ (brs, 1H), 2.29-2.22 (m, 1H), 2.16-1.88 (m, 16H), 1.67 (s, 3H), 1.63 $(\mathrm{s}, 3 \mathrm{H}), 1.59(\mathrm{~s}, 9 \mathrm{H}), 1.51-1.43(\mathrm{~m}, 2 \mathrm{H}), 1.40-1.30(\mathrm{~m}, 1 \mathrm{H}), 1.11(\mathrm{~s}, 3 \mathrm{H})$; ${ }^{13} \mathrm{C}-\mathrm{NMR}\left(100 \mathrm{MHz}, \mathrm{CDCl}_{3}\right) \delta 135.8,135.0,134.9,131.3,124.4,124.2,124.1$, 124.0, 85.8, 76.1, 67.9, 39.8, 39.7, 31.9, 30.6, 26.7, 26.6, 26.3, 25.7, 25.1, 23.1, 17.7, 16.1, 16.0, 15.9; HRMS (FAB, $m$-NBA) $[\mathrm{M}+\mathrm{H}]^{+}$calcd for $\mathrm{C}_{27} \mathrm{H}_{47} \mathrm{O}_{2}$ 403.3570, found 403.3576

tert-Butyldimethyl $(3-((2 R, 3 R)-2-$ methyl-3- $((3 E, 7 E)-4,8,12-$ trimethyltrideca-3,7,11-trien-1-yl)oxiran-2-yl)propoxy)silane (19) To a solution of $18(1.25 \mathrm{~g}, 3.60 \mathrm{mmol})$ in THF $(20 \mathrm{ml})$ at $-78^{\circ} \mathrm{C}$ were added hexamethylphosphoramide $(3.1 \mathrm{ml}, 18.0 \mathrm{mmol})$ and $n$-BuLi $(1.64 \mathrm{M}$ in $n$-hexane, $4.4 \mathrm{ml}, 7.20 \mathrm{mmol}$ ). After stirring for $1 \mathrm{~h}$ at $-78^{\circ} \mathrm{C}$, a solution of $11(1.60 \mathrm{mg}, 4.30 \mathrm{mmol})$ in THF $(10 \mathrm{ml})$ was added dropwise to the above mixture. The resulting mixture was stirred for $40 \mathrm{~min}$ at $-78^{\circ} \mathrm{C}$, quenched with saturated aqueous $\mathrm{NH}_{4} \mathrm{Cl}$ and the aqueous phase was extracted with EtOAc. The combined organic extracts were dried over anhydrous $\mathrm{Na}_{2} \mathrm{SO}_{4}$ and concentrated under reduced pressure. The residue was briefly purified by flash column chromatography (20:1 hexane/EtOAc) to afford the corresponding coupling product, which was dissolved in DMSO $(20 \mathrm{ml})$ and treated with Pd $(\mathrm{OAc})_{2}(176 \mathrm{mg}, 0.720 \mathrm{mmol})$ and dppp $(371 \mathrm{mg}, 0.900 \mathrm{mmol})$. After stirring for $5 \mathrm{~min}$ at room temperature, $\mathrm{NaBH}_{4}(272 \mathrm{mg}, 7.20 \mathrm{mmol})$ was added to the mixture. The reaction was stirred for $50 \mathrm{~min}$ at room temperature, quenched with $\mathrm{H}_{2} \mathrm{O}$ and the aqueous phase was extracted with EtOAc. The combined organic extracts were dried over anhydrous $\mathrm{Na}_{2} \mathrm{SO}_{4}$ and concentrated under reduced pressure. Flash column chromatography (70:1 hexane/EtOAc) afforded $19(1.03 \mathrm{~g}, 2$ steps, $64 \%)$ as a colorless oil: $[\alpha]^{30} \mathrm{D}+8.20\left(c 1.00, \mathrm{CHCl}_{3}\right)$; IR (neat) 3051, 2955, 1459, 1260, $739 \mathrm{~cm}^{-1} ;{ }^{1} \mathrm{H}-\mathrm{NMR}\left(400 \mathrm{MHz}, \mathrm{CDCl}_{3}\right)$

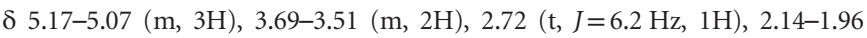
$(\mathrm{m}, 10 \mathrm{H}), 1.68(\mathrm{~s}, 3 \mathrm{H}), 1.65-1.49(\mathrm{~m}, 6 \mathrm{H}), 1.62(\mathrm{~s}, 3 \mathrm{H}), 1.59(\mathrm{~s}, 3 \mathrm{H}), 1.57$ (s, 3H), 1.25 (s, 3H), 0.88 (s, 9H), $0.04(\mathrm{~s}, 6 \mathrm{H}) ;{ }^{13} \mathrm{C}-\mathrm{NMR}\left(100 \mathrm{MHz}, \mathrm{CDCl}_{3}\right)$ $\delta 135.9,135.0,131.2,124.3,124.1,123.2,63.2,62.9,60.8,39.7,35.1,28.9,28.6$, 26.7, 26.6, 26.0, 25.8, 25.6, 24.8, 18.3, 17.7, 16.6, 16.0, 15.9, - 5.3; HRMS (EI) $[\mathrm{M}]^{+}$calcd for $\mathrm{C}_{28} \mathrm{H}_{52} \mathrm{O}_{2} \mathrm{Si}$ 448.3737, found 448.3737.

3-((2R,3R)-2-Methyl-3-((3E,7E)-4,8,12-trimethyltrideca-3,7,11-trien1-yl)oxiran-2-yl)propyl 4-methylbenzenesulfonate (20)

To a solution of $19(350 \mathrm{mg}, 0.780 \mathrm{mmol})$ in THF $(8.0 \mathrm{ml})$ at room temperature was added tetrabutylammonium fluoride $(1.0 \mathrm{M}$ in THF, $2.3 \mu \mathrm{l}$, $3.34 \mathrm{mmol}$ ). After stirring for $0.5 \mathrm{~h}$ at room temperature, the resulting mixture was quenched with brine and the aqueous phase was extracted with EtOAc. The combined organic extracts were dried over anhydrous $\mathrm{Na}_{2} \mathrm{SO}_{4}$ and concentrated under reduced pressure. This residue was employed in the next reaction without further purification. The residue was dissolved in $\mathrm{CH}_{2} \mathrm{Cl}_{2}(8.0 \mathrm{ml})$ and treated with $\mathrm{Et}_{3} \mathrm{~N}(326 \mu \mathrm{l}, 1.17 \mathrm{mmol}), \mathrm{Me}_{3} \mathrm{~N} \cdot \mathrm{HCl}(7.50 \mathrm{mg}, 0.0780 \mathrm{mmol})$ and p-TsCl $(223 \mathrm{mg}, 1.17 \mathrm{mmol})$. After stirring for $45 \mathrm{~min}$ at $0{ }^{\circ} \mathrm{C}$, the reaction was quenched with $\mathrm{H}_{2} \mathrm{O}$ and the aqueous phase was extracted with EtOAc. The combined organic extracts were dried over anhydrous $\mathrm{Na}_{2} \mathrm{SO}_{4}$ and concentrated under reduced pressure. Flash column chromatography (10:1 hexane/ EtOAc) afforded $20(355 \mathrm{mg}, 93 \%)$ as a colorless oil: $[\alpha]^{28}{ }_{\mathrm{D}}+10.3(c 1.00$, $\mathrm{CHCl}_{3}$ ); IR (neat) $3055,2986,1600,1423,1265,748 \mathrm{~cm}^{-1}$; ${ }^{1} \mathrm{H}-\mathrm{NMR}$ $\left(400 \mathrm{MHz}, \mathrm{CDCl}_{3}\right) \delta$ 7.79-7.76 (m, 2H), 7.35-7.32 (m, 2H), 5.14-5.07 (m, 3H), 4.07-3.97 (m, 2H), 2.65 (dd, $J=12.5,6.2 \mathrm{~Hz}, 1 \mathrm{H}), 2.44(\mathrm{~s}, 3 \mathrm{H}$,$) ,$ 2.16-1.94 (m, 10H), 1.78-1.70 (m, 2H) $1.67(\mathrm{~s}, 3 \mathrm{H}), 1.60(\mathrm{~s}, 3 \mathrm{H}), 1.59(\mathrm{~s}, 6 \mathrm{H})$,
1.57-1.48 (m, 4H), $1.19(\mathrm{~s}, 3 \mathrm{H}) ;{ }^{13} \mathrm{C}-\mathrm{NMR}\left(100 \mathrm{MHz}, \mathrm{CDCl}_{3}\right) \delta$ 144.7, 138.9, 136.1, 135.0, 133.1, 131.3, 129.8, 127.9, 124.3, 123.0, 70.3, 63.0, 60.0, 39.7, 34.4, $28.8,26.7,26.5,25.7,24.8,24.6,21.6,17.7,16.5,16.0$; HRMS (FAB, $m$-NBA) $[\mathrm{M}+\mathrm{H}]^{+}$calcd for $\mathrm{C}_{29} \mathrm{H}_{45} \mathrm{O}_{4} \mathrm{~S} 489.3034$, found 489.3039 .

\section{2-(3-((2R,3R)-2-Methyl-3-((3E,7E)-4,8,12-trimethyltrideca-3,7,}

\section{1-trien-1-yl)oxiran-2-yl)propyl)isoindoline-1,3-dione (21)}

To a solution of $20(381 \mathrm{mg}, 0.780 \mathrm{mmol})$ in DMF (19 ml) was added potassium phthalimide $(173 \mathrm{mg}, 0.936 \mathrm{mmol})$. After stirring for $15 \mathrm{~min}$ at room temperature, the reaction was quenched with saturated aqueous $\mathrm{Na}_{2} \mathrm{~S}_{2} \mathrm{O}_{3}$ and the aqueous phase was extracted with EtOAc. The combined organic extracts were dried over anhydrous $\mathrm{Na}_{2} \mathrm{SO}_{4}$ and concentrated under reduced pressure. Flash column chromatography (10:1 hexane/EtOAc) afforded 21 (299 mg, 83\%) as a colorless oil: $[\alpha]^{23}{ }_{\mathrm{D}}+4.95\left(c 0.100, \mathrm{CHCl}_{3}\right)$; IR (neat) 3020 , 1712, 1216, $755 \mathrm{~cm}^{-1} ;{ }^{1} \mathrm{H}-\mathrm{NMR}\left(400 \mathrm{MHz}, \mathrm{CDCl}_{3}\right) \delta$ 7.96-7.93 (m, $\left.2 \mathrm{H}\right)$, 7.83-7.80 (m, 2H), 5.40-5.17 (m, 3H), 3.81-3.76 (m, $2 \mathrm{H}), 2.82(\mathrm{t}, J=6.2 \mathrm{~Hz}$, $1 \mathrm{H}), 2.27-2.03(\mathrm{~m}, 10 \mathrm{H}), 1.90-1.83(\mathrm{~m}, 2 \mathrm{H}), 1.77(\mathrm{~s}, 3 \mathrm{H}), 1.75-1.59(\mathrm{~m}, 13 \mathrm{H})$, 1.35 (s, 3H); ${ }^{13} \mathrm{C}-\mathrm{NMR}\left(100 \mathrm{MHz}, \mathrm{CDCl}_{3}\right) \delta 168.3,136.0,135.0,133.9,133.9$, $133.8,132.1,131.2,124.3,124.1,60.0,60.2,39.7,39.6,37.8,35.9,28.8,26.7$, 26.6, 25.6, 24.3, 24.2, 17.7, 16.5, 16.4, 16.0; HRMS (FAB, $m$-NBA) $[\mathrm{M}+\mathrm{H}]^{+}$ calcd for $\mathrm{C}_{30} \mathrm{H}_{42} \mathrm{O}_{3} \mathrm{~N}$ 465.3157, found 465.3165 .

\section{$(R, 4 E, 8 E)-5,9,13-T r i m e t h y l-1-((S)-2-m e t h y l p y r r o l i d i n-2-y l)$} tetradeca-4,8,12-trien-1-ol (7)

To a solution of $21(35.7 \mathrm{mg}, 0.108 \mathrm{mmol})$ in THF $(2.0 \mathrm{ml})$ was added $\mathrm{NH}_{2} \mathrm{NH}_{2} \cdot \mathrm{H}_{2} \mathrm{O}(67 \mu \mathrm{l}, 2.16 \mathrm{mmol})$. After stirring for 2 days at room temperature, flash column chromatography $\left(10: 1 \quad \mathrm{CH}_{2} \mathrm{Cl}_{2} / \mathrm{MeOH}\left(1 \% \mathrm{NH}_{3}\right.\right.$ aq. $\left.)\right)$ afforded $7(20.9 \mathrm{mg}, 58 \%)$ as a colorless oil: $[\alpha]^{22} \mathrm{D}-3.15\left(c 0.50, \mathrm{CHCl}_{3}\right)$; IR (neat) 3437, 3055, 2982, 1634, 1424, 1266, $746 \mathrm{~cm}^{-1}$; ${ }^{1} \mathrm{H}-\mathrm{NMR}(400 \mathrm{MHz}$, $\left.\mathrm{CDCl}_{3}\right) \delta 5.18-5.07(\mathrm{~m}, 3 \mathrm{H}), 3.27(\mathrm{dd}, J=10.1,1.9 \mathrm{~Hz}, 1 \mathrm{H}), 3.08-3.02$ (m, 1H), 2.94-2.88 (m, 1H), 2.34-2.25 (m, 1H), 2.14-1.89 (m, 9H), 1.88-1.72 $(\mathrm{m}, 3 \mathrm{H}), 1.68(\mathrm{~s}, 3 \mathrm{H}), 1.63(\mathrm{~s}, 3 \mathrm{H}), 1.59(\mathrm{~s}, 6 \mathrm{H}), 1.56-1.44(\mathrm{~m}, 1 \mathrm{H})$, $1.42-1.21(\mathrm{~m}, 2 \mathrm{H}), 0.87(\mathrm{~s}, 3 \mathrm{H}) ;{ }^{13} \mathrm{C}-\mathrm{NMR}\left(100 \mathrm{MHz}, \mathrm{CDCl}_{3}\right) \delta 135.4$, 134.9, 131.3, 124.4, 124.3, 124.2, 76.2, 64.9, 45.7, 39.7, 39.6, 32.2, 30.7, 26.8, $26.6,25.7,24.6,22.6,17.8,16.0,15.9,15.8$; HRMS (FAB, $m$-NBA) $[\mathrm{M}+\mathrm{H}]^{+}$ calcd for $\mathrm{C}_{22} \mathrm{H}_{40} \mathrm{ON} 334.3103$, found 334.3110 .

\section{$(5 S, 6 S)-5-M e t h y l-6-((3 E, 7 E)-4,8,12$-trimethyltrideca-3,7,11-trien-1-} yl)-1-azabicyclo[3.1.0] hexane (23)

To a solution of $21(42.0 \mathrm{mg}, 0.0906 \mathrm{mmol})$ in THF $(1.8 \mathrm{ml})$ was added $\mathrm{NH}_{2} \mathrm{NH}_{2} \cdot \mathrm{H}_{2} \mathrm{O}(11.3 \mu \mathrm{l}, 0.362 \mathrm{mmol})$. After stirring for $12 \mathrm{~h}$ at $50^{\circ} \mathrm{C}$, flash column chromatography $\left(10: 1 \quad \mathrm{CH}_{2} \mathrm{Cl}_{2} / \mathrm{MeOH}\left(1 \% \mathrm{NH}_{3}\right.\right.$ aq. $)$ ) afforded 23 (17.4 mg, 61\%) and $7(3.0 \mathrm{mg}, 10 \%)$ as colorless oils: $[\alpha]^{21} \mathrm{D}-6.09(c 1.00$, $\mathrm{CHCl}_{3}$ ); IR (neat) 3052, 2931, 2856, 1443, 1266, $745 \mathrm{~cm}^{-1} ;{ }^{1} \mathrm{H}-\mathrm{NMR}$ $\left(400 \mathrm{MHz}, \mathrm{CDCl}_{3}\right) \delta 5.17-5.11(\mathrm{~m}, 3 \mathrm{H}), 2.92-2.87(\mathrm{~m}, 1 \mathrm{H}), \quad 2.61-2.87$ $(\mathrm{m}, 1 \mathrm{H}), 2.43(\mathrm{dd}, J=10.5,2.7 \mathrm{~Hz}, 1 \mathrm{H}), 2.20-1.92(\mathrm{~m}, 10 \mathrm{H}), 1.75-1.63$ $(\mathrm{m}, 2 \mathrm{H}), 1.68(\mathrm{~s}, 3 \mathrm{H}), 1.62(\mathrm{~s}, 3 \mathrm{H}), 1.65-1.58(\mathrm{~m}, 1 \mathrm{H}), 1.60(\mathrm{~s}, 6 \mathrm{H})$, $1.53-1.28(\mathrm{~m}, 3 \mathrm{H}), 1.15(\mathrm{~s}, 3 \mathrm{H}) ;{ }^{13} \mathrm{C}-\mathrm{NMR}\left(100 \mathrm{MHz}, \mathrm{CDCl}_{3}\right) \delta 135.8$, 135.0, 131.3, 124.3, 124.1, 123.8, 70.5, 64.5, 43.2, 39.7, 37.8, 29.7, 27.9, 26.7, $26.6,25.7,25.3,23.7,22.4,17.7,16.1,16.0$; HRMS (FAB, $m$-NBA) $[\mathrm{M}+\mathrm{H}]^{+}$ calcd for $\mathrm{C}_{22} \mathrm{H}_{38} \mathrm{~N} 316.3008$, found 316.3004 .

\section{$S$-(3-((2R,3R)-2-Methyl-3-((3E,7E)-4,8,12-trimethyltrideca-3,7,11-} trien-1-yl)oxiran-2-yl)propyl) ethanethioate (22)

To a solution of $20(84.0 \mathrm{mg}, 0.172 \mathrm{mmol})$ in DMF $(1.00 \mathrm{ml})$ was added KSAc $(98.1 \mathrm{mg}, 0.859 \mathrm{mmol})$. After stirring for $30 \mathrm{~min}$ at room temperature, the reaction was quenched with $\mathrm{H}_{2} \mathrm{O}$ and the aqueous phase was extracted with EtOAc. The combined organic extracts were dried over anhydrous $\mathrm{Na}_{2} \mathrm{SO}_{4}$ and concentrated under reduced pressure. Flash column chromatography (30:1 hexane/EtOAc) afforded $22(59.7 \mathrm{mg}, 88 \%)$ as a colorless oil: $[\alpha]^{21} \mathrm{D}+0.027$ (c 1.00, $\mathrm{CHCl}_{3}$ ); IR (neat) 2965, 1694, 1448, 1383, 1133, $625 \mathrm{~cm}^{-1}$; ${ }^{1} \mathrm{H}-\mathrm{NMR}\left(400 \mathrm{MHz}, \mathrm{CDCl}_{3}\right) \delta 5.16-5.07$ (m, 3H), 2.88-2.84 $(\mathrm{m}, 2 \mathrm{H}), 2.70(\mathrm{t}, J=6.4 \mathrm{~Hz}, 1 \mathrm{H}), 2.32(\mathrm{~s}, 3 \mathrm{H}), 2.17-1.95(\mathrm{~m}, 10 \mathrm{H})$, $1.74-1.47(\mathrm{~m}, 6 \mathrm{H}), 1.67(\mathrm{~d}, J=0.8 \mathrm{~Hz}, 3 \mathrm{H}) 1.62(\mathrm{~s}, 3 \mathrm{H}), 1.59(\mathrm{~s}, 6 \mathrm{H}), 1.24$ $(\mathrm{s}, 3 \mathrm{H}) ;{ }^{13} \mathrm{C}-\mathrm{NMR}\left(100 \mathrm{MHz}, \mathrm{CDCl}_{3}\right) \delta 195.8,136.2,135.2,131.4,124.5,124.3$, 
$123.3,63.3,60.5,60.5,39.9,39.8,37.9,30.8,29.1,26.9,26.7,25.8,25.6,25.0$, $17.8,16.7,16.2,14.3$; HRMS (ESI+) $[\mathrm{M}+\mathrm{Na}]^{+}$calcd for $\mathrm{C}_{24} \mathrm{H}_{40} \mathrm{NaO}_{2} \mathrm{~S}$ 415.2647, found 415.2655 .

\section{$(R, 4 E, 8 E)-5,9,13-T r i m e t h y l-1-((S)-2-m e t h y l t e t r a h y d r o t h i o p h e n-2-$} yl)tetradeca-4,8,12- trien-1-ol (8) and (2R,3R)-3-methyl-2-((3E,7E)4,8,12-trimethyltrideca-3,7,11-trien-1- yl)tetrahydro- $2 H$-thiopyran3-ol (24)

Methanolysis. To a solution of $22(22.4 \mathrm{mg}, 0.0570 \mathrm{mmol})$ in $\mathrm{MeOH}(500 \mu \mathrm{l})$ was added $\mathrm{K}_{2} \mathrm{CO}_{3}(47.3 \mathrm{mg}, 0.342 \mathrm{mmol})$. After stirring for $1.5 \mathrm{~h}$ at room temperature, the reaction was quenched with $\mathrm{H}_{2} \mathrm{O}$ and the aqueous phase was extracted with EtOAc. The combined organic extracts were dried over anhydrous $\mathrm{Na}_{2} \mathrm{SO}_{4}$ and concentrated under reduced pressure. Flash column chromatography (20:1 hexane/EtOAc) afforded $8(6.00 \mathrm{mg}, 29 \%)$ and $\mathbf{2 4}$ (8.40 mg, 46\%) as colorless oils.

DIBAL reduction. To a solution of $22(102 \mathrm{mg}, 0.260 \mathrm{mmol})$ in $\mathrm{CH}_{2} \mathrm{Cl}_{2}$ $(2.59 \mathrm{ml})$ was treated with DIBAL $(1.03 \mathrm{M}$ in $n$-hexane, $1.13 \mathrm{ml}, 1.17 \mathrm{mmol})$ at $-78^{\circ} \mathrm{C}$. After stirring for $1.5 \mathrm{~h}$ at $0{ }^{\circ} \mathrm{C}, \mathrm{MeOH}$ was added dropwise at $0{ }^{\circ} \mathrm{C}$ to the resulting solution until the evolution of gas ceased. The mixture was diluted with $\mathrm{CH}_{2} \mathrm{Cl}_{2}$, treated with Celite $\left(500 \mathrm{mg}\right.$ ) and $\mathrm{Na}_{2} \mathrm{SO}_{4} \cdot 10 \mathrm{H}_{2} \mathrm{O}$ (500 mg), and then stirred for $1 \mathrm{~h}$ at $0{ }^{\circ} \mathrm{C}$. The resulting suspension was filtered through a pad of Celite and the filtrate was concentrated under reduced pressure. The residue was purified by flash column chromatography (15:1 hexane/EtOAc) to afford $8(56.9 \mathrm{mg}, 63 \%)$ and $24(5.10 \mathrm{mg}, 6 \%)$ as colorless oils.

8. $[\alpha]^{21} \mathrm{D}+0.028\left(c\right.$ 0.71, $\mathrm{CHCl}_{3}$ ); IR (neat) 3450, 2927, 1636, 1377, $552 \mathrm{~cm}^{-1} ; \quad{ }^{1} \mathrm{H}-\mathrm{NMR} \quad\left(400 \mathrm{MHz}, \quad \mathrm{CDCl}_{3}\right) \quad \delta \quad 5.17-5.07 \quad(\mathrm{~m}, \quad 3 \mathrm{H})$, $3.48(\mathrm{dd}, J=1.8,10.2 \mathrm{~Hz}, 1 \mathrm{H}), 2.94-2.81(\mathrm{~m}, 2 \mathrm{H}), 2.32-2.23(\mathrm{~m}, 1 \mathrm{H})$, $2.20-1.93(\mathrm{~m}, 12 \mathrm{H}), 1.67(\mathrm{~d}, J=0.8 \mathrm{~Hz}, 3 \mathrm{H}), 1.63(\mathrm{~s}, 3 \mathrm{H}), 1.59(\mathrm{~s}, 6 \mathrm{H})$, $1.71-1.51(\mathrm{~m}, 2 \mathrm{H}), 1.43-1.34(\mathrm{~m}, 1 \mathrm{H}), 1.38(\mathrm{~s}, 3 \mathrm{H}) ;{ }^{13} \mathrm{C}-\mathrm{NMR}(100 \mathrm{MHz}$, $\left.\mathrm{CDCl}_{3}\right) \delta 135.8,135.0,131.3,124.4,124.2,124.0,76.6,64.1,39.7,37.7,33.7$, $32.1,31.0,26.7,26.7,26.6,25.7,25.6,17.7,16.1,16.0$; HRMS (ESI+) $[\mathrm{M}+\mathrm{Na}]^{+}$ calcd for $\mathrm{C}_{22} \mathrm{H}_{38} \mathrm{NaOS}$ 373.2541, found 373.2534.

24. $\left.[\alpha]^{21} \mathrm{D}-0.167 \quad(c) 0.52, \mathrm{CHCl}_{3}\right)$; IR (neat) 3445, 2925, 1455, 1286, $548 \mathrm{~cm}^{-1}$; ${ }^{1} \mathrm{H}-\mathrm{NMR}\left(400 \mathrm{MHz}, \mathrm{CDCl}_{3}\right) \delta 5.13-5.10(\mathrm{~m}, 3 \mathrm{H}), 2.47$ $(\mathrm{d}, J=11.6 \mathrm{~Hz}, 1 \mathrm{H}), 2.32-2.27(\mathrm{~m}, 2 \mathrm{H}), 2.13-1.93(\mathrm{~m}, 11 \mathrm{H}), 1.84-1.78$ $(\mathrm{m}, 1 \mathrm{H}), 1.76-1.70(\mathrm{~m}, 1 \mathrm{H}), 1.69-1.55(\mathrm{~m}, 2 \mathrm{H}), 1.68(\mathrm{~s}, 3 \mathrm{H}), 1.63(\mathrm{~s}, 3 \mathrm{H})$, $1.60(\mathrm{~s}, 6 \mathrm{H}), 1.49-1.45(\mathrm{~m}, 1 \mathrm{H}),, 1.25(\mathrm{~s}, 3 \mathrm{H}) ;{ }^{13} \mathrm{C}-\mathrm{NMR}\left(100 \mathrm{MHz}, \mathrm{CDCl}_{3}\right)$ $\delta$ 136.2, 135.0, 131.3, 124.3, 124.1, 123.4, 69.4, 52.3, 39.7, 39.7, 36.0, 28.4, 26.7, 26.6, 26.4, 25.7, 25.4, 24.5, 23.9, 17.7, 16.1, 16.0; HRMS (ESI+) $[\mathrm{M}+\mathrm{Na}]^{+}$calcd for $\mathrm{C}_{22} \mathrm{H}_{38} \mathrm{NaOS}$ 373.2541, found 373.2531.

\section{CONFLICT OF INTEREST}

The authors declare no conflict of interest.

\section{ACKNOWLEDGEMENTS}

This research was partially supported by a Grant-in-Aid for Scientific Research (C) from the ministry of Education, Culture, Sports, Science and Technology (MEXT) of Japan (SA, 2350132) and Kitasato University research grant for young researchers (MO). We thank Ms N Sato and Dr K Nagai (Kitasato University) for kindly measuring NMR and MS spectra.

1 Omura, S. et al. An anthelmintic compound, nafuredin, shows selective inhibition of complex I in helminth mitochondria. Proc. NatI Acad. Sci. USA 98, 60-62 (2001).

$2 \mathrm{Ui}, \mathrm{H}$. et al. Nafuredin, a novel inhibitor of NADH-fumarate reductase, produced by Aspergillus niger FT-0554. J. Antibiot. 54, 234-238 (2001).

3 Takano, D. et al. Absolute configuration of nafuredin, a new specific NADH-fumarate reductase inhibitor. Tetrahedron Lett. 42, 3017-3020 (2001).

4 Takano, D. et al. Total synthesis of nafuredin, a selective NADH-fumarate reductase inhibitor. Org. Lett. 3, 2289-2291 (2001).

5 Nagamitsu, T. et al. Total synthesis of nafuredin- $\gamma$, a $\gamma$-lactone related to nafuredin with selective inhibitory activity against NADH-fumarate reductase. Tetrahedron Lett. 44, 6441-6444 (2003).

6 Shiomi, K et al. A $\gamma$-lactone form nafuredin, nafuredin- $\gamma$, also inhibits helminth complex I. J. Antibiot. 58, 50-55 (2005).

7 Nagamitsu, T. et al. The total synthesis and biological evaluation of nafuredin- $\gamma$ and its analogues. Tetrahedron 64, 8117-8127 (2008).

8 Ohtawa, M. et al. Design, synthesis, and biological evaluation of air-stable nafuredin- $\gamma$ analogs as complex I inhibitors. Bioorg. Med. Chem. 23, 932-943 (2015).

9 Uyanik, M., Ishihara, K. \& Yamamoto, H. Catalytic diastereoselective polycyclization of homo(polyprenyl)arene analogues bearing terminal siloxyvinyl groups. Org. Lett. 8, 5649-5652 (2006)

10 Appel, R. Tertiary phosphane/tetrachloromethane, a versatile reagent for chlorination, dehydration, and P-N Linkage. Angew. Chem. Int. Ed. 14, 801-811 (1975).

11 Hoshino, T., Chiba, A. \& Abe, N. Lanosterol biosynthesis: the critical role of the methyl29 group of 2,3-oxidosqualene for the correct folding of this substrate and for the construction of the five-membered D ring. Chem. Eur. J. 18, 13108-13116 (2012).

12 Trost, B. M. \& Braslau, R. Tetra-n-butylammonium oxone. Oxidations under anhydrous conditions. J. Org. Chem. 53, 532-537 (1988).

13 Trost, B. M., Dong, G. \& Vance, J. A. Cyclic 1,2-diketones as core building blocks: a strategy for the total synthesis of (-)-terpestacin. Chem. Eur. J. 16, 6265-6277 (2010)

14 Amino, H. et al. Stage-specific isoforms of Ascaris suum complex. II: the fumarate reductase of the parasitic adult and the succinate dehydrogenase of free-living larvae share a common iron-sulfur subunit. Mol. Biochem. Parasitol. 106, 63 (2000).

15 Brioche, J. C. R., Goodenough, K. M., Whatrup, D. J. \& Harrity, J. P. A. A [3+3] annelation approach to (+)-rhopaloic acid B. Org. Lett. 9, 3941-3943 (2007).

16 Baldwin, J. E. Rules for ring closure. J. Chem. Soc. Chem. Commun. 734-736 (1976).

Supplementary Information accompanies the paper on The Journal of Antibiotics website (http://www.nature.com/ja) 